\title{
PRODUKTIVITAS TENAGA KERJA KELUARGA DALAM PEMELIHARAAN SAPI PERAH DI KECAMATAN GETASAN KABUPATEN SEMARANG
}

\author{
Bambang Sudarmanto', Krishna Agung Santosa ${ }^{2}$ dan F. Trisakti Haryadi ${ }^{2}$
}

\section{INTISARI}

Pemeliharaan sapi perah pada peternakan rakyat sebagian besar dilaksanakan oleh tenaga kerja keluarga. Tujuan penelitian ini adalah untuk mengetahui: tenaga kerja keluarga yang dibutuhkan untuk setiap jenis kegiatan yang dilakukan, produktivitas tenaga kerja keluarga, dan faktor-faktor yang mempengaruhi produktivitas tenaga kerja keluarga serta kontribusi pendapatan usaha sapi perah terhadap pendapatan usahatani secara keseluruhan. Materi penelitian adalah peternak sapi perah di Kecamatan Getasan, Kabupaten Semarang, yang memiliki sapi perah dewasa satu ekor atau lebih dan telah memulai usahanya minimal dua tahun. Sejumlah enam desa sample diambil secara acak dari 13 desa yang ada, sedangkan responden diambil secara proportional random sampling. Analisis yang digunakan untuk mengetahui faktor-faktor yang berpengaruh terhadap produktivitas tenaga kerja keluarga digunakan regresi linier berganda. Dari penelitian diperoleh hasil bahwa Kepala Keluarga merupakan tenaga kerja yang mencurahkan tenaganya paling banyak 5,073 jam kerja setara pria (JKSP) atau 55,12\% dari total tenaga kerja, disusul istri $2,374 \mathrm{JKSP}(25,80 \%)$ dan anak laki-laki 0,903 JKSP $(9,81 \%)$. Tenaga kerja yang paling banyak dibutuhkan adalah pada jenis kegiatan mencari pakan hijauan $(45,75 \%)$. Produktivitas tenaga kerja keluarga dalam pemeliharaan sapi perah sebesar Rp. $38.230,93$ per hari orang kerja (HOK) dengan pendapatan Rp. 16.752,94 per HOK. Faktor yang berpengaruh positif terhadap produktivitas tenaga kerja keluarga adalah persentase anggota keluarga yang lulus SLTA, jumlah kepemilikan sapi perah dan ternak selain sapi perah serta keikutsertaan anggota keluarga dalam pelatihan pengelolaan sapi perah $(\mathrm{P}<0,01)$. Faktor yang berpengaruh negatif adalah lama usaha dijalankan $(\mathrm{P}<0,10)$, jumlah anggota keluarga $(\mathrm{P}<0,05)$, dan luas lahan selain untuk HMT $(\mathrm{P}<0,01)$. Pendapatan usaha sapi perah memberikan kontribusi sebesar $76,10 \%$ terhadap pendapatan usahatani secara keseluruhan.

(Kata kunci : Produktivitas tenaga kerja keluarga, Peternakan sapi perah rakyat).

Buletin Peternakan $29(2): 97-105,2005$

'Sekolah Tinggi Penyuluhan Pertanian (STPP) Magelang.

${ }^{2}$ Fakultas Peternakan Universitas Gadjah Mada, Yogyakarta. 


\title{
THE FAMILIY LABOUR PRODUCTIVITY OF DAIRY FARMING IN GETASAN DISTRICT, SEMARANG REGENCY
}

\begin{abstract}
Most of dairy farming of small holders were executed by family labour. The objectives of this research were to know: family labour was required for activities within farming, family labour productivity, the factors influencing family labour productivity and contribution of dairy income to total of farm income. Farmers of dairy cattle in Getasan District, Regency of Semarang having one head of adult dairy cattle and two years experience, were taken as respondents. Six of 13 villages were drawn randomly, while respondents were drawn by proportional random sampling. Multiple linear regression was used to analyze factors affecting family labour productivity. The results indicated that: head of household mostly spent his work for 5.073 man-hours or $55.12 \%$ of his total man-hours, followed by wife 2.374 man-hours $(25.80 \%)$, and son 0.903 man-hours $(9.81 \%)$. The highest labour allocation was for forage cut and carry $(45.75 \%)$. The family labour productivity was found to be Rp $38,230.93$ per man-day, with the income of $\mathrm{Rp} 16,752.94$ per man-day. Percent of family members finishing from high school, number of dairy cattle and other animals, participation of farmers to dairy training, were the factors positively affecting $(\mathrm{P}<.01)$, while experience $(\mathrm{P}<.10)$, land wide not used for forage $(\mathrm{P}<.01)$, number of family members $(\mathrm{P}<.05)$ negatively affecting family labour productivity. Contribution of dairy cattle income was $76.10 \%$ of total farm income.
\end{abstract}

(Key words : Family labour productivity, Small-holder dairy farm).

\section{Pendahuluan}

Subsektor peternakan merupakan bagian dari sektor pertanian yang memiliki prospek baik. Hal ini mengingat kesadaran masyarakat akan konsumsi protein hewani terus meningkat sehingga permintaan akan produksi peternakan seperti daging, telur dan susu juga terus meningkat. Namun walaupun demikian, efisiensi usahapun harus terus diupayakan agar dapat memiliki daya saing tinggi mengingat semakin banyak ternak dan produksi hasil ternak yang masuk dari negara lain dengan segala keistimewaannya.

Sistem pemeliharaan ternak yang dilakukan pada peternakan rakyat masih sangat sederhana sehingga seluruh anggota keluarga tani dapat ikut serta dalam pemeliharaan temak ini untuk mengisi waktu luangnya. Waktu luang bagi petani di pedesaan cukup banyak mengingat kecilnya usaha tani yang dijalankan, adanya tenaga kerja keluarga tani yang berlebihan, adanya produksi musiman, serta kurangnya sumber penghidupan lain diluar pertanian secara luas (Tohir, 1983).

Adiwilaga (1982), menyatakan persediaan tenaga kerja dalam perusahaan pertanian adalah tenaga dari pengusaha/petani ditambah anggota keluarga yang sudah dapat turut bekerja, perhitungan tenaga kerja setara pria (TKSP) yang berlaku dikalangan pertanian untuk petani, istri, anak laki-laki berumur 15 dan 10 tahun maka berturut-turut adalah sebesar: 1; 0,$75 ; 1 ; 0,5$ TKSP dan dapat bekerja penuh dalam 8 jamperhari.

Produktivitas tenaga kerja disektor pertanian ditentukan oleh kesediaan faktorfaktor sarana produksi, investasi atau penggunaan teknologi serta aktivitas yang dilakukan oleh tenaga kerja itu sendiri (Sinaga, 1978 yang disitasi Wiguna, 1995). Perhitungan produktivitas tenaga kerja menurut Sinungan (2000), adalah dengan membagi kuantitas hasil dengan kuantitas penggunaan masukan tenaga kerja, dimana masukan tenaga kerja dapat dihitung dalam jam kerja setara pria (JKSP), hari 
orang kerja (HOK), ataupun dalam perhitungan waktu kerja satu tahun. Sementara itu Aroef (1983), mengatakan bahwa produktivitas tenaga kerja merupakan perbandingan dari jumlah hasil kerja dengan waktu yang diperlukan dari seorang tenaga kerja.

Sagir (1989) menyatakan bahwa produktivitas tenaga kerja sangat dipengaruhi oleh: (1) latar belakang pendidikan dan latihan yang telah diikuti (2) alat-alat produksi yang digunakan dan teknologi dalam proses produksi (3) nilai-nilai atau pranata sosial masyarakat dan juga faktor lingkungan hidup, kuat tidaknya ikatan keluarga, motivasi dan mobilitasnya (4) derajat kesehatan tenaga kerja, nilai gizi, sanitasi, tersedianya air bersih di lingkungan kerja (5) kondisi iklim dan lingkungan kerja sekitar, serta (6) tingkat upah yang diterima tenaga kerja. Menurut Simanjuntak (1985), faktor faktor yang mempengaruhi produktivitas tenaga kerja adalah umur, pendidikan dan pengalaman dari tenaga kerja itu sendiri.

Seperti halnya ternak yang lain, sistem pemeliharaan sapi perah di Indonesia pada peternakan rakyat dilakukan secara tradisional. Ciri umum peternakan sapi perah rakyat adalah rendahnya ketrampilan peternak, kecilnya modal usaha, kecilnya jumlah ternak produktif dan cara pemberian ransum yang masih sederhana (Kusnadi, 1982).

Kecamatan Getasan di Kabupaten Semarang, Propinsi Jawa merupakan salah satu wilayah pensuplai susu di Jawa Tengah. Jumlah ternak yang dipelihara oleh petani peternak barvariasi, namun demikian rata-rata di bawah enam ekor yang pemeliharaannya dilakukan oleh tenaga kerja keluarga. Tujuan dari penelitian ini adalah untuk mengetahui (1) tenaga kerja keluarga dibutuhkan untuk setiap jenis kegiatan yang dilakukan dalam pemeliharaan sapi perah (2) produktivitas tenaga kerja keluarga dalam pemeliharaan sapi perah (3) faktor-faktor karakteristik keluarga dan karakteristik situasional yang mempengaruhi produktivitas tenaga kerja keluarga dalam pemeliharaan sapi perah, serta (4) kontribusi pendapatan usaha sapi perah terhadap pendapatan usahatani secara keseluruhan.

\section{Materi dan Metode}

Materi penelitian adalah peternak sapi perah yang berada di Kecamatan Getasan, Kabupaten Semarang, Propinsi Jawa Tengah yang memiliki jumlah sapi perah dewasa satu ekor atau lebih dan telah menekuni usahanya minimal dua tahun.

Metode yang digunakan dalam penelitian ini adalah dengan metode survey terhadap 60 peternak. Penelitian dilaksanakan selama tiga bulan dari bulan Juli sampai September 2004. Didalam pemilihan desa sampel diambil secara acak 6 desa dari 13 desa di Kecamatan Getasan. Pengambilan responden secara proportional random sampling (Suryabrata, 1992).

Untuk menjawab tujuan penelitian yang pertama dan kedua akan dipaparkan secara deskriptif tenaga kerja keluarga yang dibutuhkan untuk setiap jenis kegiatan pemeliharaan sapi perah serta besarnya produktivitas tenaga kerja keluarga. Untuk menjawab tujuan yang ketiga dan membuktikan hipotesis digunakan analisis regresi linier berganda (Gujarati, 1995; Soekartawi 1994). Persamaan dari perhitungan produktivitas tenaga kerja keluarga dituliskan sebagai berikut:

$$
\operatorname{Pr}=a+b_{1} X 1+b_{2} X_{2}+\ldots .+b_{8} X_{8}+b_{9} D+e
$$

Keterangan:

$\mathrm{Pr}=$ Produktivitas tenaga kerja keluarga (Rp/HOK)

$\mathrm{a}=$ konstanta atau intersep

$\mathrm{b}_{1} \mathrm{~b}_{9}=$ koefisien regresi masing-masing variabel

$X_{1}=$ Proporsi anggota keluarga yang menyelesaikan pendidikan SLTA(\%)

$\mathrm{X}_{2}=$ Lamanya usaha peternakan dilakukan (th)

$\mathrm{X}_{3}=$ Jumlah anggota keluarga (TKSP)

$\mathrm{X}_{4}=$ Proporsi tenaga kerja keluarga laki-laki (\%) 
$\mathrm{X}_{5}=$ LuaslahanHMT(ha)

$\mathrm{X}_{6}=$ Luas lahan selain untuk budidaya HMT(ha)

$\mathrm{X}_{7}=$ Jumlah kepemilikan sapi perah (ST)

$\mathrm{X}_{8}=$ Jumlah kepemilikan ternak selain sapi perah (ST)

D = Keikutsertaan anggota keluarga dalam mengikuti pendidikan non formal atau kursus pengelolaan sapi perah

1 : pernah ada yang mengikuti

0 : belum pernah ada yang mengikuti

$\mathrm{e}=$ Tingkat kesalahan

Di dalam mengestimasi koefisien regresi digunakan metode kuadrat terkecil atau ordinary least square (OLS), sedangkan untuk menguji ketepatan model digunakan uji tingkat ketepatan: nilai $\mathrm{R}^{2}$, uji F dan uji t (Gujarati, 1995).

Menurut Soekartawi (1995), untuk mengetahui kontribusi pendapatan usaha sapi perah terhadap pendapatan usahatani secara keseluruhan dan agar dapat digunakan untuk menjawab tujuan yang keempat dapat dihitung dengan rumus:

$$
\mathrm{Ksp}=\frac{\mathrm{Ysp}}{\text { Yut }} \times 100 \%
$$

Keterangan:

Ksp : Kontribusi usaha sapi perah terhadap usahatani keseluruhan

Ysp : Pendapatan usaha sapi perah

Yut : Pendapatan usahatani

\section{Hasil dan Pembahasan}

\section{Keberadaan sapi perah dan karakteristik peternak}

Populasi sapi perah di kecamatan Getasan sebanyak 20.983 ekor merupakan $69,09 \%$ dari seluruh populasi yang ada di Kabupaten Semarang dengan produksi susu sebesar 14.740.695 liter atau 68,37\% (Anonimus, 2004). Tingkat pendidikan peternak sebagian besar lulus Sekolah Dasar $(80 \%)$. Umur peternak berkisar antara 23.73 tahun atau rata-rata 46,22 tahun, lama usaha 9,4 tahun dengan jumlah anggota keluarga 4,27 jiwa dan tenaga kerja keluarga sebesar 3,37 jiwa (2,79 TKSP). Apabila kita lihat jumlah anggota keluarga yang lulus SLTA dengan seluruh jumlah anggota keluarga secara keseluruhan sebesar 10,16\% dengan prosentase tenaga kerja keluarga laki-laki sebesar $52,97 \%$. Peternak sapi perah di wilayah ini yang telah mengikuti kursus pengelolaan sapi perah baru $15 \%$.

Jumlah kepemilikan sapi perah rata-rata 5,08 ekor $(3,72 \mathrm{ST})$, sedangkan kepemilikan ternak selain sapi perah hanya sebesar 0,03 ST. Luas lahan untuk penanaman HMT rata-rata seluas 0,44 ha, yang berarti lebih luas dari pada lahan untuk tanaman lain seluas 0,29 ha. Kegiatan dalam pengelolaan sapi perah yang dilakukan oleh tenaga kerja luar keluarga hanya 0,356 JKSP atau 3,868\% dari seluruh tenaga kerja yang dibutuhkan untuk pengelolaan sapi perah, sedangkan sisanya 8,847 JKSP atau $96,132 \%$ dilakukan oleh tenaga kerja keluarga. Tenaga kerja yang dibutuhkan untuk setiap jenis kegiatan dalam pemeliharaan sapi perah dapat dilihat pada Tabel 1 .

Tenaga yang digunakan untuk mencari pakan hijauan merupakan yang terbesar dari kegiatan pemeliharaan ternak yaitu 4,21 JKSP atau $45,75 \%$ dari seluruh waktu yang dicurahkan untuk pemeliharaan sapi perah. Setelah itu secara berturut-turut adalah memberi pakan $1,154 \mathrm{JKSP}$ $(12,54 \%)$, membersihkan kandang 0,906 JKSP $(9,84 \%)$, memerah sapi 0,84 JKSP $(9,13 \%)$, memberi minum 0,810 JKSP $(8,80 \%)$ dan seterusnya sampai yang paling sedikit waktu digunakan adalah memupuk HMT yaitu 0,05 JKSP $(0,54 \%)$.

\section{Pendapatan pemeliharaan sapi perah}

Biaya yang diperhitungkan dalam pemeliharaan sapi perah dibedakan menjadi biaya tetap dan biaya tidak tetap. Besarnya biaya total rata-rata pertahun untuk setiap peternak dalam pemeliharaan sapi perah adalah $\mathrm{Rp}$. $8.540 .513,53$ atau Rp. 2.295.839,65/ST.

Penerimaan usaha sapi perah bagi peternak di Kecamatan Getasan berasal dari: produksi susu, nilai tambah temak, dan pupuk kandang. Rata-rata setiap peternak memiliki sapi laktasi sebanyak 2,68 ekor atau 52,76\% dari jumlah ternaknya. Penerimaan rata-rata pertahun 
Tabel 1. Rata-rata Tenaga kerja dibutuhkan untuk setiap jenis kegiatan yang dilakukan Dalam pemeliharaan sapi perah perhari $\left(\mathrm{JKSP}^{\mathrm{a}}\right)^{\mathrm{b}}$ (Time alocation of family members to conduct dairy farming perday)

\begin{tabular}{|c|c|c|c|c|c|c|c|c|}
\hline Jenis kegiatan (Activities) & $\mathrm{KK}^{\mathrm{c}}$ & IST $^{d}$ & $\overline{\mathrm{AL}^{\mathrm{e}}}$ & $\overline{\mathrm{AP}^{t}}$ & $\overline{A K L^{g}}$ & $\mathrm{TKL}^{\mathrm{h}}$ & $\begin{array}{l}\text { Jumlah } \\
\text { (Total) } \\
\end{array}$ & $\%$ \\
\hline $\begin{array}{l}\text { Mencari pakan } \\
\text { (Collectingforage) }\end{array}$ & 2,258 & 1,165 & 0,341 & 0,075 & 0,104 & 0,267 & 4,210 & 45,75 \\
\hline $\begin{array}{l}\text { Memberi pakan } \\
\text { (Feeding) }\end{array}$ & 0,661 & 0,280 & 0,129 & 0,038 & 0,029 & 0,017 & 1,154 & 12,54 \\
\hline $\begin{array}{l}\text { Memberi minum } \\
\text { (Preparing drinking } \\
\text { water) }\end{array}$ & 0,362 & 0,278 & 0,075 & 0,067 & 0,020 & 0,008 & 0,810 & 8,80 \\
\hline $\begin{array}{l}\text { Membersihkan kandang } \\
\text { (Washing stable) }\end{array}$ & 0,586 & 0,108 & 0,124 & 0,030 & 0,025 & 0,033 & 0,906 & 9,84 \\
\hline $\begin{array}{l}\text { Membersihkan ternak } \\
\text { (Cleaning cattle) }\end{array}$ & 0,266 & 0,022 & 0,029 & 0,001 & 0 & 0,009 & 0,327 & 3,55 \\
\hline $\begin{array}{l}\text { Memerah } \\
\text { (Milking) }\end{array}$ & 0,51 & 0,183 & 0,095 & 0,040 & 0,008 & 0,004 & 0,840 & 9,13 \\
\hline $\begin{array}{l}\text { Memupuk HMT } \\
\text { (Fertilizing plantation) }\end{array}$ & 0,042 & 0,002 & 0,002 & 0 & 0,001 & 0,003 & 0,054 & 0,54 \\
\hline $\begin{array}{l}\text { Membeli pakan } \\
\text { (Buying feed) }\end{array}$ & 0,063 & 0,033 & 0,017 & 0,006 & 0,002 & 0 & 0,121 & 1,31 \\
\hline $\begin{array}{l}\text { Mencuci peralatan } \\
\text { kandang }\end{array}$ & & & & & & & & \\
\hline $\begin{array}{l}\text { (Cleaning equipment) } \\
\text { Menjual susu }\end{array}$ & 0,184 & 0,117 & 0,031 & 0,027 & 0,002 & 0,008 & 0,369 & 4,01 \\
\hline $\begin{array}{l}\text { (Selling milk) } \\
\text { Lain-lain }\end{array}$ & 0,098 & 0,186 & 0,047 & 0,012 & 0,009 & 0 & 0,352 & 3,82 \\
\hline (Others) & 0,043 & 0 & 0,013 & 0,001 & 0 & 0,007 & 0,064 & 0,70 \\
\hline $\begin{array}{l}\text { Jumlah } \\
\text { (Total) } \\
\text { Persentase (\%) }\end{array}$ & 5,073 & 2,374 & 0,903 & 0,297 & 0,200 & 0,356 & 9,203 & \\
\hline (Percentage) & 55,12 & 25,80 & 9,81 & 3,22 & 2,17 & 3,87 & & 100,0 \\
\hline
\end{tabular}

${ }^{\mathrm{a}}$ Jam kerja setara pria (Man-hours); ${ }^{\mathrm{b}} \mathrm{Jumlah}$ sapi perah rata-rata 3,72 satuan ternak (Amount of average dairy cattle 3,72 animal unit); ${ }^{\mathrm{c}}$ Kepala keluarga (Head of household); ${ }^{\mathrm{d}}$ Istri (Wife); ${ }^{\mathrm{e}}$ Anak laki-laki (Sons); ${ }^{\mathrm{f}}$ Anak perempuan (Doughters); ${ }^{8}$ Anggota keluarga yang lain (Other family members); ${ }^{\text {h }}$ Tenaga kerja upah (Payment labour).

untuk setiap keluarga dalam pemeliharaan sapi perah sebesar Rp. 14.763.017,67 atau Rp. $3.968 .553,14 / \mathrm{ST}$.

Pendapatan rata-rata peternak dari hasil pembiayaan dan penerimaan usaha Rp. 6.222.504,04 pertahun atau sebesar Rp. $17.047,96$ perhari. Sehingga dengan demikian apabila dikonversikan dengan rata-rata keterlibatan anggota keluarga maka pendapatan pemeliharaan sapi perah ini adalah sebesar $\mathrm{Rp}$. $16.752,94$ per HOK, meskipun dalam kenyataannya tidak diterimakan secara langsung pada tenaga kerja keluarga, tetapi menjadi pendapatan keluarga. Pendapatan perHOK ini lebih besar dari upah minimum regional (UMR) di Kabupaten Semarang sebesar Rp. 15.543,33 per hari dan diatas rata-rata UMR propinsi Jawa tengah secara keseluruhan sebesar Rp. 14.085,87 perhari(Anonimus, 2005).

\section{Produktivitas tenaga kerja keluarga}

Produktivitas tenaga kerja keluarga dalam pemeliharaan sapi perah adalah total penerimaan usaha sapi perah oleh tenaga kerja keluarga 
cita-cita dan harapan untuk dapat hidup yang lebih baik. Pada masyarakat yang seperti ini inovasi yang ditawarkan akan sangat lambat diadopsi.

Produktivitas tenaga kerja keluarga dalam pemeliharaan sapi perah dipengaruhi pula secara negatif oleh Jumlah anggota keluarga $(\mathrm{P}<0,05)$. $\mathrm{Hal}$ ini bisa terjadi mengingat tenaga kerja keluarga yang semakin banyak tidak diikuti dengan jumlah kepemilikan ternak yang semakin banyak, serta pengelolaan yang lebih baik. Dikemukakan oleh Adiwilaga (1982), bahwa pada pertanian dan peternakan rakyat terdapat penggunan tenaga kerja yang berlebihan sehingga menyebabkan kurangnya efisiensi penggunaan tenaga kerja. Ditambahkan oleh Sudono (1984), bahwa untuk mencapai efisiensi tenaga kerja sebaiknya 6 sampai 7 ekor sapi dewasa dibutuhkan satu orang tenaga kerja, sementara di kecamatan getasan setiap tenaga kerja hanya menangani rata-rata 1,33 sapi perah dewasa.

Luas lahan yang digarap peternak selain untuk tanaman HMT berpengaruh negatif terhadap produktivitas tenaga kerja keluarga dalam pemeliharaan sapi perah $(\mathrm{P}<0,01)$, kondisi ini dapat dipahami mengingat hasil samping dan sisa hasil dari tanaman pertanian di Kecamatan Getasan seperti tembakau cabe, tanaman bunga tidak bisa dijadikan sebagai pakan sapi perah atau bila ada waktu yang dibutuhkan tidak tepat.

\section{Kontribusi pendapatan sapi perah terhadap pendapatan usahatani keluarga}

Hasil usaha tani tanaman dan ternak selain sapi perah, petani memperoleh pendapatan rata-rata sebesar Rp. 1.954.628,92 pertahun, sedangkan dari pendapatan pemeliharaan sapi perah diperoleh pendapatan sebesar Rp. 6.222.504,14 pertahun. Dengan demikian pendapatan usahatani keluarga secara keseluruhan sebesar Rp. 8.177.132,92, atau dapat dikatakan bahwa usaha sapi perah akan memberikan kontribusi terhadap usahatani keluarga rata-rata sebesar $76,10 \%$.

Kontribusi pendapatan sapi perah terhadap pendapatan usahatani secara keseluruhan apabila dihitung dalam HOK akan mendapatkan hasil $37,28 \%$. Kontribusi ini masih tergolong tinggi mengingat pendapatan dari kegiatan usahatani yang lain adalah gabungan dari beberapa cabang usahatani baik tanaman maupun ternak.

\section{Kesimpulan}

Hasil penelitian produktivitas tenaga kerja keluarga dalam pemeliharaan sapi perah di Kecamatan Getasan Kabupaten Semarang dapat disimpulkan bahwa tenaga kerja keluarga yang dibutuhkan untuk setiap jenis kegiatan pemeliharaan sapi perah (JKSP) adalah: mencari pakan 3,943; memberi pakan 1,137; memberi minum 0,802 ; membersihkan kandang 0,873 ; membersihkan ternak 0,318 ; memerah 0,836 ; memupuk HMT 0,051; membeli pakan 0,121; mencuci peralatan kandang 0,361; menjual susu 0,352 ; dan kegiatan yang lain seperti mendeteksi birahi, melapor kondisi ternak ke pos IB dan POSKESWAN, dan lain-lain sebesar 0,057.

Produktivitas tenaga kerja keluarga dalam pemeliharaan sapi perah sebesar Rp. $38.230,93$ per HOK, dengan pendapatan sebesar RP. 16.752,94 per HOK. Faktor yang tenaga kerja keluarga dalam pemeliharaan sapi perah adalah: persentase anggota keluarga yang lulus SLTA, jumlah kepemilikan sapi perah dan kepemilikan ternak selain sapi perah, serta keikutsertaan anggota keluarga dalam kursus pengelolaan sapi perah $(\mathrm{P}<0,01)$, faktor yang berpengaruh negatif adalah: lama usaha pemeliharaan sapi perah dijalankan $(\mathrm{P}<0,10)$, jumlah anggota keluarga $(\mathrm{P}<0,05)$, dan luas lahan selain untuk HMT $(\mathrm{P}<0,01)$, sedangkan proporsi tenaga kerja laki-laki dan luas lahan untuk HMT tidak berpengaruh. Pendapatan usaha pemeliharaan sapi perah memberikan kontribusi sebesar $76,10 \%$ terhadap pendapatan usahatani keluarga secara keseluruhan.

\section{Daftar Pustaka}

Adiwilaga, A. 1982. Ilmu Usaha Tani. Penerbit Alumni, Bandung.

Anonimus, 2004. Profil Dinas Peternakan dan Perikanan Kabupaten Semarang Tahun 2003. Dinas Peternakan dan Perikanan 
Kabupaten Semarang, Ungaran.

Anonimus, 2005. Upah Minimum pada 35 (Tiga Puluh Lima) Kabupaten/Kota di Propinsi Jawa Tengah. Keputusan Gubernur Jawa Tengah No. 561/54/2004.

Aroef, M. 1983. Pengertian Produktivitas, Kertas Kerja. Dewan Produktivitas Nasional, Jakarta.

Gujarati, D.N. 1995. Basic Econometrics. $3^{\text {rd }}$ ed. Mc Graw Hill International Editions, Singapura.

Kusnadi, U. 1982. Analisis Usaha Sapi Perah yang Tergabung dalam Koperasi di Daerah Istimewa Yogyakarta. Tesis Fakultas Pascasarjana Universitas Gadjah Mada, Yogyakarta.

Mardikanto, T. 1993. Penyuluhan Pembangunan Pertanian. Sebelas Maret University Press, Surakarta.

Mathis, R. L. dan J. H. Jackson, 2002. Manajemen Sumberdaya Manusia (terjemahan). Penerbit Salemba Empat, Jakarta.

Sagir. 1989. Kesempatan Kerja, Ketahanan Nasional, dan Pembangunan Manusia Seutuhnya. Penerbit Alumni, Bandung.

Simanjuntak, J.P. 1985. Masalah Tenaga Kerja di Indonesia. Departemen Tenaga Kerja, Jakarta.

Sinungan, 2000. Produktivitas, Apa dan Bagaimana. Bumi Aksara, Jakarta.
Soekartawi. 1994. Teori Ekonomi Produksi, Pokok Bahasan Analisis Fungsi Cobb Douglas. PT. Raja Grafindo Persada, Jakarta.

Staton, T.F. 1978. Cara Mengajar dan Hasil yang Baik (Terjemahan) CV. Diponegoro, Bandung.

Sudono, A. 1984. Produksi Sapi Perah. Fakultas Peternakan, Institut Pertanian Bogor, Bogor.

Suryabrata, S. 1992. Metodologi Penelitian. Rajawali Pers, Jakarta.

Tjiptoherijanto, P. 1996. Ketimpangan Ekonomi dan Kecemburuan Sosial. Majalah Manajemen Pembangunan, No. 15/IV/1996, Jakarta.

Tohir, A. K. 1983. Seuntai Pengetahuan tentang Usahatani Indonesia. Bagian I edisi I. PT Bina Aksara, Jakarta.

Wiguna, M. A., 1995. Analisis Penyerapan Tenaga Kerja di Subsektor Peternakan. Pidato Pengukuhan Jabatan Lektor Kepala pada Fakultas Peternakan Universitas Gadjah Mada, Yogyakarta.

Yusuf, I. S., A. Thoyib, dan Kusnadi. 1998. Analisis efisiensi ekonomi relatif dan perolehan skala pada usahatani sapi perah. Studi kasus di kecamatan sendang, kabupaten temanggung. Wacana Jumal Penelitian Ilmu-Ilmu Sosial. Vol 1, No $1 / 1988$. 